\title{
A Construção de um Processo Gestão Estratégica de Humanização a Partir da Técnica de Grupo Nominal
}

\author{
Ruthes, Vanessa Roberta Massambani \\ Pontifícia Universidade Católica do Paraná — vanessa_ruthes@yahoo.com.br
}

INTRODUÇÃO a Política Nacional de Humanização do Ministério da Saúde, criada em 2003, possui, três objetivos centrais, que reúnem em si a necessidade de priorizar a qualidade assistencial e o respeito a dignidade do usuário, como também a necessidade de repensar a gestão dos processos de trabalho. ao contrário do que muitos teóricos afirmam a humanização não é humanizar o humano, mas repensar a globalidade dos processos que tem como finalidade tornar digna a assistência à saúde, fundamentados em uma nova relação entre os profissionais de saúde e entre estes e os usuários, bem como em uma nova forma de gestão dos processos de saúde. para que estes objetivos e intuitos possam ser alcançados é necessário e fundamental o desenvolvimento de um plano gerencial de curto, médio e longo prazo que viabilize de forma efetiva a realização dos mesmos. Tendo como premissa que a humanização, como área temática da Bioética é interdisciplinar, a construção deste plano deve ser fundamentada na gestão participativa. Neste sentido compusemos 6 Grupos de Trabalho para que fosse desenvolvida uma Política de Humanização a partir da realidade de Hospitais que balizasse todo o processo de gestão. OBJETIVOS: Constituir uma Política de Humanização que norteie os processos de gestão de Hospistais. MÉTODOS: para estruturar um Documento de Humanização é necessário que o processo deste seja participativo, tendo em vista não só a interdisciplinariedade, mas também os diferentes olhares clínicos e de gestão. para tanto foi utilizada a Técnica de Grupo Nominal que constitui-se uma metodologia divergente e convergente, em que ocorre tanto a produção de ideias individuais, como a partir da discussão presencial, um esclarecimento do assunto a ser validado para o grupo, bem como a priorização de ideias. Sendo que a partir destas foram definidas Áreas Diretrizes, Dispositivos de Ação e Parâmetros de Avaliação. RESULTADOS a partir da constituição básica do documento, com seus princípios operativos, submeteu-se o mesmo a validação dos Hospitais e posteriormente foi realizado um desdobramento, fundamentado na Política de Humanização, de um Programa de Gestão Estratégica que já está em desenvolvimento. CONCLUSÕES Percebeu-se de forma nítida que a Humanização entendida como Processo de Gestão Estratégica proporciona uma efetividade maior no desenvolvimento de uma cultura humanista nos Hospitais. Tendo em vista que a mesma passa de uma simples execução de projetos ou ações isoladas para a ampliação e aprofundamento da ação humanizadora.

Ruthes, Vanessa Roberta Massambani. A Construção de um Processo Gestão Estratégica de Humanização a Partir da Técnica de Grupo Nominal. In: Anais do Congresso Internacional de Humanidades \&

Humanização em Saúde [= Blucher Medical Proceedings, num.2, vol.1]. São Paulo: Editora Blucher, 2014. ISSN 2357-7282

DOI 10.5151/medpro-cihhs-10434 